\title{
THE CORRESPONDENCE OF WALT WHITMAN: A Fourth Supplement with Addenda to the Calendar of Letters Written to Whitman
}

\author{
Edited by Ted Genoways
}

\section{INTRODUCTION}

WHEN I PUBLISHED SIXTY-EIGHT unpublished and uncollected letters in the Summer/Fall 2000 issue of $W W Q R$, I never imagined that I would have another thirty-three letters to present less than two years later. The initial grouping was largely the result of new ways of uncovering Whitman manuscripts and increasingly democratic access to auction items through sources such as eBay. This new collection, however, is more akin to exciting discoveries of years past, and I am delighted and honored to have been a part of it.

This new supplement has its roots in the December 2000 auction at Christie's of the largest collection of Whitman materials made available in my lifetime. Ed Folsom contacted me about the sale and asked me to review the auction catalog for unpublished letters. Working with that list and a list of other important manuscripts compiled by Folsom, Dr. Kendall Reed went about systematically acquiring as many of these items as possible.

It is hard for me to express my gratitude for Ken Reed's approach to collecting. Where some have sought to find and hoard unknown manuscripts, he has been an integral partner of Whitman scholars. Of the twelve unpublished letters I identified from the Christie's auction, Dr. Reed was able to acquire nine-pursuing most aggressively those letters that were not reproduced in facsimile. He invited Folsom and me to his home in early 2001 for a day of transcription and conversation. Since then I have continued to expand this grouping by locating items on the World Wide Web, via auction and bookseller sites. Whenever possible, Reed has acquired items not available in transcript or facsimile. Of the 101 letters gathered in this and the previous supplement, twenty are from the collection of Dr. Kendall Reed.

I have also continued to search newly archived collections as they come online and to comb documented collections for unpublished items. When the New York Public Library announced that the Lion and Berg collection finding aids were now available online, I was able to uncover 
two unpublished postcards from my desk at home. Ed Folsom was kind enough to copy these items during one of his planned research trips to the NYPL.

Doing some of my own legwork and using the Notebooks and Unpublished Prose Manuscripts as my guide, I was also able to uncover several draft letters on an East Coast trip in November 2001. I transcribed the reverse side of several items listed in the NUPM as written on the "verso of a draft letter." In the course of doing this research, I also stumbled across occasional unexpected gems-none more surprising than a previously undocumented letter from the Trent Collection which the librarian informed me had been found several years ago by the Trent family in "the middle drawer of an old desk."

Whatever their source, new letters continue to come and-I suspect-will continue to come for some time. The sole downside of this plenty is that it has grown increasingly difficult for scholars to locate letters. Two years ago I described my hope that sometime in the future, "with the aid of advancing technology, a database of Whitman's letters will no doubt be available," and I have reiterated this hope below. Unfortunately, that is a long-range goal, and in the meantime letters are now scattered among several discrete publications: Edwin Haviland Miller's original five volumes of the Correspondence in The Collected Writings of Walt Whitman; the addenda in Volume 5; Volume 6, the first supplement to the Correspondence, produced in small quantities and now almost entirely unavailable; Miller's 1991 second supplement, published as a special issue of $W W Q R$; the third supplement I edited in 2000; and the collection presented here. This decentralized approach means that each potential new discovery now must be checked against six different sources.

While it would take years to create a centralized, chronological, and regularly updated database, it is a more immediately realizable goal to gather the letters from the second, third, and fourth supplements, all originally published in $W W Q R$, along with new discoveries made in the interim, into a formal Volume 7 of The Collected Writings of Walt Whitman: The Correspondence. I hope to complete that project soon; in the meantime, it is my earnest hope that this supplement will provide a ready resource to these exciting discoveries and that these new letters will shed yet more light on the life of our beloved and elusive poet.

I must close again by acknowledging with gratitude the work of the late Edwin Haviland Miller, a lifetime of labor on Whitman's correspondence that has made my few contributions possible. I'm pleased that this special issue of $W W Q R$ is dedicated to him. My thanks also to all the institutions and individuals who provided access to their manuscripts and the permission to publish them. Thanks, too, to all the scholars and researchers who helped make this possible. Special thanks go to: Ed Folsom for his unflagging encouragement and guidance, as well 
as his transcriptions of the two postcards from the NYPL; Ken Price for uncovering the postcard at the Cahill book site; Ken Reed for his unbelievable support of Whitman studies; and always to Mary Anne Andrei, my wife, who outdid herself by putting up with constant talk of Whitman even while she was studying for her qualifying exams.

\section{A LIST OF WHITMAN'S CORRESPONDENTS}

This alphabetical list includes all the recipients of letters printed in this supplement. The name is followed by the letter number.

Alden, William Livingston, 242.8

Arnold, James, 751.5

Baxter, Sylvester, 1629.5

Brown, Leonard Morgan, 2185.5

Century Illustrated Monthly Review, 1417

Cox, George C., 1563

Donaldson, Thomas, 1387

Drewry, Louisa, 2250

Eldridge, Charles W., 1272.5

Emerson, Ralph Waldo, 26

Ford, Isabella, 1248.5

Gilder, Jeanette, 1048.1

Harper's Magazine, 560.5

Heyde, Hannah, 2582.5

Hine, Charles, 396.1

Johnston, Alma, 1372

Johnston, Dr. John, 2633.1

Kennedy, William Sloane, 2251, 2421

McKay, David, 1464.8, 2678.2

Morrison, B. G., 737.5

New York Herald, 147.5

Ritter, Fanny R., 908.2

Sholes, C. H., 908.3

Skinner, William C., 1310.5

Sun, The, 1074.2

Unidentified Correspondents, 727.1, 855.8, 941.5, 945.8, 977.5

Vines, Sydney H., 840.9

Whitman, Thomas Jefferson, 1561.1

\section{ABBREVIATIONS}

Corr The Collected Writings of Walt Whitman: The Correspondence (19611977), ed. Edwin Haviland Miller

CT Complete Text

DBN Daybooks and Notebooks (1978), ed. William White

Feinberg Charles E. Feinberg Collection, the Library of Congress

LC The Library of Congress

NUPM Notebooks and Unpublished Prose Manuscripts (1984), ed. Edward F. Grier 


$\begin{array}{ll}\text { PT } & \text { Partial Text } \\ \text { PW } & \text { Prose Works } 1892 \text { (1963-1964), ed. Floyd Stovall } \\ \text { WW } & \text { Walt Whitman } \\ \text { WWQR } & \text { Walt Whitman Quarterly Review } \\ \text { WWWC } & \text { With Walt Whitman in Camden (1906-1982), ed. Horace Traubel } \\ & \text { and others }\end{array}$

\section{A NOTE ON THE TEXT}

Those familiar with Edwin Haviland Miller's volumes of The Collected Writings of Walt Whitman: The Correspondence will recognize the numbering system here; however, it bears reiteration. Letters, as they were gathered and published, were arranged chronologically and assigned numbers. When new letters were discovered, they were given the number of the preceding letter plus a decimal-such as, 344.5. Enough time has passed and enough new letters uncovered that certain difficulties have arisen with the numbering system. The most obvious example was Arthur Golden's discovery of eight new letters in 1986, all of which predated the first previously-known letter, thus forcing Miller to number them .01-.08. At some future date, with the aid of advancing technology, a database of Whitman's letters will no doubt be available, and the numbering system which has served us so well for forty years will no longer be necessary.

In the meantime, the additional letters presented here are numbered according to the old system. To accommodate new letters that may yet be discovered, the numbers following a decimal point have been selected according to their relative space between dates. For example, Whitman's newly discovered letter to Charles Hine on July 14, 1871, has been assigned 396.1, because letter 396 was written earlier in the day on July 14, but letter 397 was not begun until July 16. Conversely, Whitman's letter to Sydney H. Vines, on November 27, 1877, has been assigned 840.9 , because another letter was written to Edward Carpenter on that same day, noting "have to-day mailed $\mathrm{Mr}$ Vines' books," making an additional letter in between unlikely. Nevertheless, the arrangement is a matter of reserving space rather than representing some authoritative chronology.

In cases where letters here do not carry decimals points-as with letters 26,1563 , or 2421 , for example - these letters represent more complete versions than those previously available. In some cases it may be the addition of only a line or two; in others it may be whole new pages. Whatever the case, they are treated as new items that replace the previous partial texts that occupied their numbers. Some remain partial texts or transcripts and, with any luck, will soon be replaced themselves.

As with Miller's editions, the heading of each letter contains the name of the recipient, but the date is given only when Whitman did not supply the full or accurate date in the body of the letter. In cases where dates have been inserted for undated letters, explanations have been supplied in footnotes. Where no date can be determined, numbers have been assigned at the end of Miller's numbering system. A subheading before the text includes the way that Whitman 
addressed the letter, as well as any postmark information, whenever an associated envelope is available or the back of a postcard is accessible. The present location of these letters, if known, is supplied in a line after the text, along with any information of previous partial or complete publication.

26.

$$
\text { To Ralph Waldo Emerson }
$$

ENDORSED (by WW): “R. W. Emerson. | W Whitman | 1863.”

Washington, D. C. | Monday afternoon, Dec. 29, '62.

Dear friend,

Breaking up a few weeks since, and for good, my New York stagnation-wandering since through camp and battle scenes-I fetch up here in harsh and superb plight-wretchedly poor, excellent well, (my only torment, family matters) - realizing at last that it is necessary for me to fall for the time in the wise old way, to push my fortune, to be brazen, and get employment, and have an income-determined to do it, (at any rate until I get out of horrible sloughs) I write you, asking you as follows:

I design to apply personally direct at headquarters, for some place. I would apply on literary grounds, not political.

I wish you would write for me something like the enclosed form of letter, that I can present, opening my interview with the great man. I wish you to write two copies - put the one in an envelope directed to Mr. Seward, Secretary of State - and the other in an envelope directed to $\mathrm{Mr}$. Chase, Secretary of the Treasury-and enclose both envelopes in the one I send herewith so that I can use either one or the other. I wish you also to send me a note of introduction to Charles Sumner. ${ }^{1}$

It is pretty certain that, armed in that way, I shall conquer my object. Answer me by next mail, for I am waiting here like ship waiting for the welcome breath of the wind.

Indeed yours, \&c

Walt Whitman

ENCLOSURE: The bearer Mr. Walt Whitman, a literary man of distinction, is from Brooklyn, New York. He desires employment as a clerk in the departments or in any way in which he can be serviceable to the government. I commend him to the favorable consideration of any of the heads of the departments who may need his services.

MS: Emerson Memorial Association, Harvard. CT: Rusk, ed. The Letters of Ralph Waldo Emerson (1939), 5:302. Enclosure: Yale. Verso of "Adieu for the Present" (\#53). 
1 William Henry Seward (1801-1872), Secretary of State (1861-1869); Salmon Portland Chase (1808-1873), Secretary of the Treasury (1861-1864); Charles Sumner (18111874), chairman of the Committee on Foreign Affairs, United States Senate (18611871). Emerson wrote to Seward and Chase on January 10, and to WW on January 12, 1863.

\subsection{To the Editor of the New York Herald ${ }^{1}$ 12.26-29(?).1864}

DRAFT.

Private note to Editor.

Sir I respectfully ask you to print this communication written to start a public demand for the general exchange of prisoners of war. ${ }^{2}$ As the question now stands, the fault is altogether with our government. I hope you will feel to say a word editorialy about it, perhaps call attention in that way to the communication.

I solicit that you will find room for it to-morrow morn'g as I have sent this afternoon similar communications to one or two other papers, (though this one is different in form \& made specialy for the Herald.

MS: Huntington Public Library.

1 Between December 26 and 29, WW sent copies of his article "The Prisoners" to several newspaper editors, including the Brooklyn Daily Eagle and the New York Times. See letters 147 and 148 for similar letters of solicitation.

2 WW's fervor for a general exchange of prisoners was born from his inability to effect a special exchange for his brother George, who, WW had told Ellen M. O'Connor earlier in the month, "still remains a prisoner-as near as we can judge he is at Columbia, S C—we have had no word from him—" (Corr 1:244).

242.8 To William Livingston Alden, Associate Editor of the New York Citizen

Washington, D.C., 10 August 1867.

W. L. Alden.

My dear Sir:

Your note has been received. ${ }^{1}$ - Accept-for yourself, the Citizen, \& Gen. Halpine ${ }^{2}-$ My sincere thanks for your kindness. I fully appreciate it.

As I have not at my control, at this moment, any bound copies of Leaves of Grass, would you allow me to send you a copy in paper I forward it by same mail with this. ${ }^{3}$

I send best remembrances to the General. 
MS: Kendall Reed Collection.

1 Alden wrote WW on August 9, 1867, to inform him that "Citizen Rosetti's article" would appear in the Citizen the following day (WWWC, 3:259). No copies of the Citizen prior to 1869 have survived, but WW appears to have read and enjoyed the article. 2 Charles G. Halpine (1829-1868) was a journalist, soldier, and politician. He joined the 69th New York Regiment at the outbreak of the war and was brevetted brigadier general for gallantry. Known as a humorist and author, under the pseudonym Pvt. Miles O'Reilley, Halpine was also a well-known journalist who wrote for the New York Herald, and later became editor of The Leader. It would appear that, in 1867, Halpine was writing for the Citizen.

3 This is in response to Alden's request for “a copy of your book-a thing I don't possess" (WWWC, 3:259).

\subsection{To Charles Hine ${ }^{1}$}

ADDREss: Charles Hine | artist | New Haven | Connecticut

Brooklyn

Friday afternoon, July 14. [1871]

Charles Hine,

Dear, dear friend,

I shall try and come to New Haven, very soon-though but for perhaps two or three hours. For some days past my mother has been illsome of the time very ill - and I have been nurse \& doctor too, as none of my sisters are home at present-But to-day she seems over it, if the favorable symptoms continue. ${ }^{2}$

I have procured the portrait $\&$ frame without any trouble, ${ }^{3} \&$ they are now hanging up in mother's front room- $-\&$ are the delight $\&$ ever-increasing gratification of my folks \& friends, young \& old-some of whom sit by the half hour \& just look steadily at it in silence-It is indeed a noble piece of work-manship - age has already improved it, \& will still more-both painting \& frame were unharmed-Mr. Blondell, 806 Broadway, had the painting, \& has others of yours. ${ }^{4}$

Dear Charley, I cannot fix the day, but I will indeed try to come forthwith. I too wish to be with you once more-though it will be but so briefly-5

Much love to you, my dear firend,- - not forgetting your wife \& children.

Walt Whitman 
MS: Kendall Reed Collection.

1 Charles Hine (1827-1871) was the painter who created the oil painting, from which the engraving that became the frontispiece for the 1860 edition of Leaves of Grass was made. In a letter now lost, Whitman appears to have received word from Hine that that he was very ill. On July 26, WW wrote to William D. O'Connor that "an artist friend of mine is very low there with consumption-is in fact dying" (Corr 2:130).

2 In letters written the same day to Peter Doyle and William D. O'Connor, Whitman describes caring for his mother in almost identical terms.

3 It appears that Hine gave the portrait he had painted of Whitman to him as a dying gift.

4 Jacob D. Blondel (1817-1877), one of Hine's acquaintances and a fellow portrait painter; Dodworth Hall at 806 Broadway in New York City was one of several buildings in which artists rented studio space from the 1850s to 1870s. WW's old friend Jesse Talbot rented space there at the same time as Hine.

5 On July 26, WW started out for New Haven and stayed that night and all the next day with Hine. He wrote Peter Doyle, "I thought he would die while I was there-he was all wasted, to a skeleton, faculties good, but voice only a low whisper-I returned last night after midnight-" (Corr 3:131). Within ten days, Hine died; his wife wrote to Whitman: "It is useless for me to tell you how strong his affection was for you, and how he has looked forward to you coming to N. H. I think that after your visit to him that his hold on life seemed to give way and his yearnings were all accomplished" (WWWC 3:330).

560.5 To Harper's Magazine

12.15 .1873

\section{To foreman in Composing Room}

Harper's Magazine

After correcting "Prayer of Columbus," please-the editor consenting-take two impressions, (proofs) similar to this \& send me in this envelope for my private use for future preservation

Whitman

[endorsed in another hand: December 15, 1873. | Walt Whitman] ${ }^{1}$

MS: Trent.

1 This endorsement appears correct. Henry M. Alden, editor of Harper's New Monthly Magazine, accepted "Prayer of Columbus" on December 1 (Feinberg), and on December 29, WW wrote to Charles Eldridge that "Song of the Redwood Tree" and "Prayer of Columbus" were "in type, and I have read proofs. So they are off my mind" (Corr 2:264). The poems appeared in the March 1874 issue (524-525). 
ADDRESS: Pete Doyle | M st. South-

Bet $412 / 2 \& 6^{\text {th }} \mid$ Washington, D. C. POSTMARK: Camden | Sep 17 | N. J.

431 Stevens St. | cr West. Camden, N. Jersey. | Sept. 17. 4 p.m.

All going on pretty much as usual with me.- -yours of last Sunday rec'd.

WW

MS: Unknown, facsimile on eBay auction website.

1 This letter is numbered in accordance with the group of "Undated Post Cards to Peter Doyle, Probably Written in 1874 or 1875," gathered by Miller in Corr 2:347-349.

\subsection{To The Printer and Proofreader ${ }^{1}$}

To getter up of the books-Printer-Eo Proof-reader

remember this is to be a verbatim, entire $\&$ authentic edition, specially authorized by me, W.W. \& representing me.

There are to be two Vols. each Vol. complete in itself.

My idea is of rather plain, solid looking books, ordinary 12 mo (of rather small)-Can't you make a book, (say paper covers,) that would sell for a shilling sterling, each Vol? - but that I leave to you-

You had better fix on a sized page just the tally of these, so it will come in page for page. (This book is in long primer-I should like well to have the same sized type \& same general style adhered to)

Proof reader-I depend much on you-please look over all the copy first, thoroughly, get my ideas, (perhaps kinks) \& then see that they are adhered to, as the proofs come in your hands-Of course read very carefully by copy, for punctuation, capitalization, \&c-Particularly mind the spaces (leads or white lines) between the verses, (or between the passages in prose in Two Rivulets)

The little extra top heads Leaves of Grass, as on pp. 7, 29, \&c. can be left out, if desired, for condensing

The little figures to first lines of verses must go in, just as in text

(get this name below cut, wood (or as you choose) to go on title page of Leaves of Grass Walt Whitman)

MS: Texas (Hanley), CT: NUPM 4:1530. 
1 This letter to the printer and proofreader of the London reprint of LG (1876), which WW tried to engineer in February and March of that year. These instructions may have accompanied the letter of March 29 to Rossetti.

737.5 To B. G. Morrison

\section{TRANSCRIPT.}

[Whitman writes to inform Mr. Morrison that he shipped 3 volumes to him.]

MS: Unknown, description in Christie's auction catalog for the sale of December 11, 2001.

751.5 To fames Arnold, Binder

6.?. $1876^{1}$

DRAFT.

the design I gave you?-You will receive 300 plates from engraving printers in two or three days \& I will send 950 circulars for end of book-I have them ready-send over any time at 3 oclock

The style of the books (10 copies) you sent to-day is satisfactory. Go on with the remainder (590) in the same style-you will have the sheets (650 copies) of Two Rivulets in two or three days. Have you got the back-title cut according to . . . The letter . . . on back does not take well

MS: Trent. Verso of "Tramps / I shall only be too happy"

1 WW received word from Samuel W. Green, who printed the pages of the 1876 editions of Leaves of Grass and Two Rivulets, that the pages of LG would be delivered on May 24, 1876.

840.9 To Sydney H. Vines ${ }^{1}$

ADDRESS: [Sydney H Vines B A] | Christ's College, Cambridge

$$
\text { Camden New Jersey }
$$

U S America

Nov 27-I send by mail to-day to same address as this card, the two Vols. L of G-and TR - please notify me (by postal card will do) soon 
MS: Unknown, facsimile from University Archives.

1 Sydney Howard Vines (1849-1934) was among Edward Carpenter's circle of Whitman admirers in England. On November 13, Carpenter sent Whitman-in a letter now lost-Vines' request for books. On the same date he sent this letter to Vines, WW sent a letter to Carpenter, noting, "have to-day mailed Mr Vines' books" (Corr 3:103). At that time, Vines was Fellow and Lecturer in Botany at Christ's College, Cambridge, and later was named Sherardian Professor of Botany at Oxford. WW received word from Carpenter on December 19 that "I hear from Vines that your books have arrived" (WWWC 1:189). Indeed, Vines' copy of Leaves of Grass inscribed by Whitman, "Sidney H. Vines from the author," was among the books offered for sale in the Spring 2001 catalog of Bertram Rota, Ltd., an antiquarian bookseller in London.

\subsection{To an Unidentified Correspondent}

DRAFT.

Camden Thursday afternoon | March 28

My dear friends

I am still grunting \& unable to go out

MS: LC (Harned)

1 There are no entries in the $D B N$ for letters sent on this day, nor references to such a letter in the known correspondence.

908.2 To Fanny R. Ritter

\section{TRANSCRIPT.}

I think of coming your way next summer, and I should then visit you (sending you word beforehand) - I am writing this in the winter sunshine and send my warmest remembrance to you and Professor. ${ }^{2}$

\section{Walt Whitman}

MS: Transcript by Mrs. Frédéric R. Ritter, inscribed on the verso of a letter from WW to Fanny Ritter composed on February 7, 1880 (Penn). At the top of her transcript Ritter wrote: "Extracted the following, to give to a friend of mother's as an autograph." 
1 On January 26, 1879, the Philadelphia Times published WW's article "Winter Sunshine. A Trip from Camden to the Coast." The pun on the title in this brief note would seem to indicate that this is the lost letter WW wrote to Ritter noted in his $D B N$ for February 24, 1879, and that he enclosed a copy of the article.

2 Frédéric Louis Ritter, composer and professor at Vassar College, who set WW's "Two Veterans" to music in 1880.

\subsection{To an Unidentified Editor}

$11(?) . ? .1879^{2}$

\section{DRAFT.}

St. Louis

To the Editor

Let me give you some flying impromptu notes ${ }^{3}$ confessedly all too meager (a hiatus every where) of my journey starting three months since from the Atlantic Coast and so railroading through New Jersey, Penn, West Virginia, Ohio, Indiana, Illinois, Wisconsin over Kansas and the Great Plains into the very heights and heart Rocky Mountains Them reserve for a special letter with the canons, parks and Peaks. Returning to Denver for a few days, then by the southern road to Pueblo, over the Plains, to Kansas City stopping there a while. ${ }^{\star}$ Then through Missouri again to St Louis, where I have been spending a month.

MS: Berkeley.

1 Perhaps this letter was intended for Robert R. Hubach, editor of the St. Louis PostDispatch. Hubach published three interviews with WW during October 1879.

2 WW returned from his Western jaunt to St. Louis in October 1879; if he had indeed spent a month there, then this letter was written in the last days of October or sometime during November.

3 The "flying impromptu notes" were never published in newspapers or magazines; however, they appear in Specimen Days, from "Swallows on the River" through "Upon Our Land" (PW, 1:204-230).

\subsection{To An Unidentified Correspondent}

Feb: 9 '80

Loafing around for a couple of hours this fine sunny crispy day-cross'd the Delaware-walk'd up Chestnut st - everything lovely-look'd in at my friend Col: Johnston's studio ${ }^{1}$ - the sun shining bright \& I feeling all right

Walt Whitman

MS: Yale (\#54). 
1 In February 1880, WW took a trip to Philadelphia to see his friend John H. Johnston.

946.7 To C. H. Sholes ${ }^{1}$

$3.12[.1880]$

ADDRESS: C H Sholes | Glenwood | Mills Co: Iowa |

postmark: Philadelphia PA | Mar | 12 | 5 PM

Camden New Jersey

March $12 \mathrm{pm}$-Yours duly rec'd-I send you by mail to-day, to same address as this card, my Two Vols, Leaves of Grass and Two RivuletsPlease send me a card informing me if they reach you safely $-^{2}$

\section{Walt Whitman}

MS: Kendall Reed Collection. CT: Genoways, Ted. “'Ashes of Soldiers': Walt Whitman and C. H. Sholes, A New Letter and a Newspaper Article," Walt Whitman Quarterly Review, Spring 2001.

1 C. H. Sholes was a short-hand reporter in Iowa. On Decoration Day, May 30, 1880, he published an article entitled "Ashes of Soldiers" in the Iowa State Register, commending WW for his service during the Civil War.

2 Sholes received the package - an 1876 edition of Two Rivulets was recently offered for sale by D \& D Galleries of Somerville, NJ, with the inscription: "C. H. Sholes / from the author"-but if he sent a postcard confirming the shipment, WW did not note it in the daybooks.

\subsection{To An Unidentified Correspondent}

10.26. [1880?]

TRANSCRIPT.

Camden New Jersey

Oct 26. Yours with Enc: Thanks - I forward the two Vols: by mail today to same address as this card. Please notify me by postal soon as they reach you safely.

Walt Whitman

MS: James Cahill Publishing and Rare Books. 
POSTMARK: Morrisania | Aug 9 | 2 PM |

N.Y. CITY | ADDRESS: J L Gilder | Editor

Critic | 757 Broadway | New York City

Mott avenue \& 149th street Station L New York City

-I am stopping here till ab't Aug: 18-(then on to Boston)-mail me a copy of last Critic here-also send the little slips of the poem here, unless already sent $\mathrm{t}^{1}$ - I like to see my friends here-house of $\mathrm{J} \mathrm{H}$ Johnston, about 90 or 100 rods from the Mott Haven station $-^{2}$

\section{Walt Whitman}

MS: Kendall Reed Collection.

1 WW returned corrected proofs of the poem "Spirit That Form'd This Scene" on August 6 and requested "After correcting please take five slip impressions (proofs) \& send me" (Corr 3:236).

2 Ever prolific, WW wrote a piece about Mott Haven, entitled "City Notes in August," which he published in the New York Tribune on August 15.

\subsection{To the Publisher of The Sun}

POSTMARK: Camden N.J. | Nove. 29 |

7 a.m. ADDRESS: Publisher |

Daily Sun newspaper | New York City

Camden NJ Nov. 28 '81

\section{Dear Sir}

I send you my special thanks for the fifty copies of the Sun of Nov. 19 th come to hand to-day- ${ }^{1}$

\section{Walt Whitman}

MS: Berg Collection, New York Public Library.

1 "Walt Whitman and the Poetry of the Future" appeared in the New York Sun on November 19, 1881. On November 20, WW sent a card of thanks and appears to have requested copies. He noted in his $D B N$ for November 26, "recd 50 Suns" (DBN 1:273274). 


\subsection{To Isabella Ford}

POSTMARK: Camden N.J. | Dec. 8 |

Philadelphia | Dec. 81883.

ADDRESS: Isabella Ford | Adel Grange |

Leeds | England

Camden New Jersey U S America

Dec. 81883

In compliance with your late request $\&$ remittance ${ }^{1}$ (safely receivedthanks) I forward my two Vols. poems \& prose-same mail with thissame address. Will you kindly notify me by postal card soon as you get them safely?

\section{Walt Whitman}

MS: Berg Collection, New York Public Library.

1 Elizabeth (Bessie) and Isabella Ford, English friends of Edward Carpenter, ordered books on June 16, 1883 (Feinberg). On June 27, WW noted in his $D B N$ sending "L of G. \& S D. (two vols) to Bessie Ford" (DBN 2:315). Six months later Isabella ordered the same books for herself. Though no letter of receipt is currently known, WW marked the order "paid" (DBN 2:325).

\subsection{To Charles W. Eldridge}

328 Mickle street Camden New Jersey | May 18, 1884

Thank you deeply for sending the excellent picture of Father Taylor ${ }^{1}$ - just what I wanted-I have penned a short informal reminiscence of Father T (in 1859) which may be printed in a magazine-If so I shall send you a copy.

\section{Walt Whitman}

MS: Courtesy of the $19^{\text {th }}$ Century Shop.

1 On May 7, 1884, WW requested "a good photo (or other picture)" of Father Edward Thompson Taylor (1793-1871), for use in his article, but Whitman's remembrance, "Father Taylor and Oratory," did not appear until 1887. 
Feb. 7 '85-Yours just rec'd with contents (thanks) ${ }^{1}$ I forward you the Volume same mail with this-When safely rec'd. will you kindly send me a card notifying me?

\section{Walt Whitman}

MS: Unknown, facsimile on the University Archives auction website.

1 On February 5, 1885, William C. Skinner wrote to WW requesting a Centennial Edition of Leaves of Grass (LC). WW noted in his DBN sending the book on November.

1372. To Alma fohnston

[between 1878-1884] ${ }^{1}$

431 Stevens st. | Thursday afternoon | 1/2 past 2.

Dear Mrs. Johnston,

This is the queer little book, perhaps you may remember I spoke about some weeks since. It is odd in form, \& may be without attractiveness at first-but somehow I think it real good \& deep-(after you break the crust \& get a little used to it.) My Dear friend I am so sorry to hear by Johnny that you are ill, \& suffering-I wish I could send you something, or do something for your relief-

Walt Whitman

MS: Kendall Reed Collection, replaces PT: Corr 3:417.

1 Even with the complete letter now available, there is still too little information to identify a specific date. The letter was apparently written after one of WW's visits to the Johnston's in New York.

1387. To Thomas Donaldson

[4.8.1886]

328 Mickle st: Camden N J | forenoon

Dear T D

Yours of yesterday rec'd announcing the 3 o'clock P M arrangement. Opera House Chestnut above 10 th - for 15 th inst. I will be ready $\&$ on hand. ${ }^{1}$ When you come over, Sunday or any other day soon, come in the 
forenoon or before 3 in afternoon or in even'g early as convenient

Walt Whitman

MS: Kendall Reed Collection, replaces description in Corr 4:23.

1 WW delivered his Lincoln lecture at the Chestnut Street Opera House in Philadelphia on April 15.

\section{To The Editor, Century Illustrated Monthly Review}

DRAFT.

July 26 , '86

My dear Sir,

I send you the Hospital article at last. ${ }^{1}$ I have preferred to give human cases, with their emotional accompaniments, sketched on the spot, to any statistics, (although I am fully supplied with the latter). As I may work in more, or make some changes send me proof soon \& I will get it ship-shape - to be fixed when. The price of the article you want-I hope in the November number ${ }^{2}-$ is $\$ 150-\&$ I reserve the right of printing in future book.

MS: Unknown, Christie's auction catalog and subsequently offered in facsimile on eBay, replaces PT: Corr 4:38.

1 "Army and Hospital Cases" appeared in Century in October 1888. WW noted the receipt of $\$ 150$ in his daybooks for August 7, 1886.

2 "Father Taylor and Oratory" did not appear in November as WW hoped; instead it was published in February 1887.

\subsection{To David McKay}

Received from David McKay, 18th December, 1886, One Hundred and Twenty 01/100 Dollars, for royalties on my books for the last year.

Walt Whitman

MS: Unknown, University Archives online catalog. 


\subsection{To Thomas fefferson Whitman}

POSTMARK: Camden, N.J. | June | 8 PM | 87 |

ADDRESS: Thos: J Whitman | 2437 2d Carondelet Av: |

St Louis Missouri

Camden June 13

Am pretty well to-day (after being under the weather the past week)Nothing new in my affairs-I am getting along comfortably-Shall soon send tear of a new piece of mine in a magazine 1 - There is a Boston scheme afoot to get me a little house in the country or sea shore. ${ }^{2}$

Walt Whitman

MS: Kendall Reed Collection.

1 Lippincott's Monthly Magazine paid WW $\$ 50$ for the November Boughs cluster, and published the sequence in November 1887.

2 Boston friends were raising money to buy a summer cottage they hoped would improve WW's failing health. WW eventually used the money to build his extravagant mausoleum in Harleigh Cemetery - to the shock and dismay of those who had worked hardest to solicit money.

\section{To George C. Cox}

ADDRESS: Mr Cox | photographer |

cor: Broadway \& 12 th street | New York City

POSTMARK: Camden, NJ | June $14 \mid 3$ PM | 87

\section{Mickle street | Camden New Jersey June 14 '87}

Your note rec'd- \& I have been looking for the proofs, (pictures specimens) ever since, but none yet come-I have no objection to either of your plans - will sign autographically \& cooperate- send on the proofs, specimens, all of them ${ }^{1}$

\section{Walt Whitman}

MS: Trent. Replaces PT in Corr 4:101.

1 Cox proposed selling signed copies of his photographs of WW. However, when the September 1887 issue of the Century appeared with an advertisement, WW still had not seen proofs, much less signed the photographs. He wrote John H. Johnston, "He advertises . . . to sell my photo, with autograph. The latter is forged, \& the former illegal \& unauthorized" (Corr 4:118). The disagreement was quickly resolved, and WW signed photographs for Cox and returned them September 15. 


\subsection{To Sylvester Baxter}

ADDRESS: Sylvester Baxter | Herald office |

255 Washington St. | Boston Mass:

POSTMARK: Camden, NJ | Nov 16 | 4:30 PM | 87

Camden Nov. 16 '87

I send by Express a plaster head ${ }^{1}$ for WSK addressed to your care at the Herald office- $\mathrm{K}$ will call for it-It is prepaid-After $\mathrm{K}$ uses it I want it given to such gallery or public institution for Art in Boston as you $\&$ he select. Your power is absolute.

\section{Walt Whitman}

MS: Kendall Reed Collection.

1 The "plaster head" is the second of Sidney H. Morse's two plaster busts of WW. "WSK" is William Sloane Kennedy.

\subsection{To Leonard Morgan Brown ${ }^{1}$}

POSTMARK: Camden | Feb 10 | 8 PM | 90 |

Philadelphia | Feb 10 | 11 PM | PAID.

ADDRESS: Leonard Morgan Brown | Hunstanton | England

Camden New Jersey U S America

Feb: 10 '90-Yr's of Jan. 27 rec'd-Thanks-Thanks for the 5 wh- is very acceptable $\&$ opportune. Things are moving on much the same with me-am sitting up as I write $\&$ have had my supper. Am writing a little for publication but quite completely physically disabled

\section{Walt Whitman}

MS: Kendall Reed Collection.

1 On February 10, 1890, WW noted in his $D B N$ receiving $£ 5$ from Brown. The discovery of this postcard requires that a new recipient be identified for 2184 .

2250. To Louisa Drewry ${ }^{1}$

ADDRESS: Miss Drewry | South Hampstead | London, England

Camden New Jersey U S America | July 1, 1890 
In accordance with note of June 20 (rec'd. with pay, thanks) I send same mail, same address as this the two Vols. requested. Soon as they arrive w'd. you kindly send me word? (by card will do)

\section{Walt Whitman}

MS: Kendall Reed Collection. Replaces PT in Corr 5:58.

1 On June 20 Louisa Drewry, whom Buxton H. Forman mentioned in his letters of June 4 and 16 (Feinberg), requested copies of Complete Poems $\mathcal{E}$ Prose and the pocketbook edition, and sent $£ 2.8$ (Feinberg). WW noted in his daybooks for July 1, "sent the big book \& morocco b'd pocket bk form L. of G. to Miss Drewry."

\section{To William Sloane Kennedy}

TRANSCRIPT.

Camden, July 2, 1890

Have seen y'r piece, sent to H[orace Traubel] on my "Quaker traits" $\&$ like it $\&$ the statistics are right. ${ }^{1}$ - Raining today ( $\&$ very welcome) Has been a long fiercely hot spell wh' I am emerging from fairly-have lived largely on blackberries \& bread - secreting \& excreting action fair (considering old age) bladder action not good but might be worse- ${ }^{2}$

\section{Walt Whitman}

MS: Unknown, transcript on website of James Cummins Bookseller, Inc. Replaces PT: Corr 5:58.

1 "The Quaker Traits of Walt Whitman" appeared in the July issue of Horace Traubel's The Conservator.

2 In Kennedy's Reminiscences of Walt Whitman, the first sentence of this letter is transcribed more or less correctly, along with its proper date. However, Kennedy's transcript also contains the sentence, "The Transcript comes promptly and I always read it" (65). This may be part of another undocumented letter from this time period.

\section{To William Sloane Kennedy}

Camden noon-Jan: 13 '91

y'r card ab't Dutch piece to Stoddart comes-at this moment I don't know what he intends conc'g it \& all the matter but sh'l keep you fully posted. I know I sh'l like the piece. My Hollandish forebearness is some- 
thing I hug closely to. ${ }^{1}$ The next $\mathrm{N}$ A Rev: is to have a piece by me on "American Nat'l Literature" !!!- -it is touch'd off with the most careless touch I probably ever allowed my pen-you will laugh ${ }^{2}$ - y'r \& frau's nice box of plums and ginger candy came right $\&$ have done me $\&$ lots of other children great good-I have had two very bad days \& night but feel easier this noon-bad bladder trouble \& other too-but sit up \& whack away. trauble ${ }^{3}$ comes faithfully daily

\section{Walt Whitman}

MS: Library of Congress, replaces PT: Corr 5:150.

1 On January 12, Kennedy sent a postcard to WW to say that he had sent his article "Dutch Traits of Walt Whitman" to Joseph Marshall Stoddart at Lippincott's at WW's suggestion. Unfortunately, WW spoke to Harry C. Walsh, another editor at the magazine, the next day who told him "it would not prove of enough interest to their readers-specific and detailed study of ancestry" (WWWC, 7:412). Though WW told Kennedy he didn't know what Stoddart "intends conc'g it," he had already asked Traubel to retrieve the article from Stoddart. On January 16, WW wrote to Kennedy suggesting that he allow the piece to appear in Traubel's new monthly, The Conservator, where it eventually ran in the February 1891 issue.

2 "American National Literature" appeared in the March 1891 issue of North American Review. The "careless touch" that opens the essay is WW's brash response to the editor's formal request: "So you want an essay about American National Literature, (tremendous and fearful subject!) do you?"

3 In the manuscript, "trauble" (a misspelling of Traubel) appears directly under "trouble" (in the phrase "bad bladder trouble"), and the proximity has clearly led to some confusion for the aged WW (or, perhaps, he is punning on the daily appearance of both trouble and Traubel).

\subsection{To Hannah Heyde}

Camden June 29 '91

Love to you sister dear-The day has got along \& I have just time to hurry this off to catch this evng's mail. Much the same with me-hot wave here again. Am anchor'd here at my window as usual. 2 enc'd. ${ }^{1}$

\section{Walt Whitman}

MS: Kendall Reed Collection.

1 The enclosures are now lost, but WW may have sent Hannah copies of the March issue of Lippincott's, which contained a section devoted to WW's work and life. 


\section{TRANSCRIPT.}

I WW \& Dr. B[ucke] - all well—These are the title \& backing pp. of the forthcoming \& really last \& completed ed'n of $\mathrm{L}$ of $\mathrm{G},{ }^{3}$ Love to you $\&$ all the friends,

WW

MS: Unknown, CT: James S. Jaffe catalog.

1 Though no salutation appears on this note, the catalog describes the message as appearing on "a proof sheet for the title-page" of the 1892 edition of $L G$. On September 30, Johnston wrote to Horace Traubel of having received a note from WW written in the margin of "the title-page of the last edition" (Feinberg).

2 On September 20, Traubel notes that WW had requested "extra sheets" to send to friends; that same day, WW wrote to J. W. Wallace: "have just written to Dr. J[ohnston]" (Corr 5:245). There is also an envelope addressed to Johnston and postmarked September 21 in LC for which no letter previously has been found.

3 See WW's letter to Bucke on September 20 with the virtually identical description (Corr 5:245).

2678.2 To David McKay

Camden Sunday Nov: 8 '91

If the new sheets are not printed $\&$ it is convenient, take the plate of the title page first to Ferguson \& delete the 1891-'2 at bottom \& have it 1892 simply — of course do this at once \& send back to printers ${ }^{1}$

\section{Walt Whitman}

MS: Kendall Reed Collection; the letter is mounted to a front flyleaf of the first Deathbed Edition of LG.

1 WW's note arrived too late and the date appeared on the Deathbed Edition as "1891'2."' 


\section{ENVELOPES}

To Peter Doyle

$[3.22 .1876](?)^{1}$

ADDRESS: Peter Doyle | Conductor |

Office | Wash \& Georgetown RR |

Washington, D. C.

POSTMARK: New York / Mar | 22 | 18[??]

MS: Unknown, facsimile on ewolfs.com, internet auction site.

1 The postmark of this envelope has been smeared and is illegible; however, the only known letter to Doyle sent on March 22 was composed in 1876.

To Herbert Gilchrist

$[1890-1892]^{1}$

Herbert Gilchrist | Morris Jarvis farm | ,

Centreport | Suffol Co: New York |

f'm Walt Whitman | Camden New Jersey

MS: Salisbury House, Des Moines, Iowa.

1 Though there is no postmark on this envelope, Gilchrist was only at the Jarvis farm after 1890 .

\section{ADDENDA TO THE CALENDAR OF LETTERS WRITTEN TO WHITMAN}

1863

August 26. From Alvah H. Small, postmarked Williamsport, PA. Barrett.

1868

September 21. From Peter Doyle. Trent.

1875

April 28. From Frederic R. Marvin, requesting permission to reprint a poem. LC.

1876

November. From Ford Madox Brown, acknowledging receipt of $L G$ and $T R$, which WW mailed him on October 25. LC.

1880

November 24. From David Hutcheson, who had ordered books. Pennsylvania. 


\section{2}

June 1. From the Philadelphia Progress, soliciting an article on Camden. Pennsylvania.

\section{3}

October 15. From James M. Scovel. LC.

\section{4}

May 14. From Charles W. Eldridge(?), signature is illegible but the letter, an invitation to breakfast at "9 A.M. on Sunday," is written on the letterhead of the "Special Agent Treasury Department" where Eldridge worked. LC.

\section{6}

February 23. From Roberts and Perkins, Grocers, Burlington, VT, about Han's health. LC.

\section{7}

From Edward W. Searing, secretary of the Seventh Assembly District Association of the United Labor Party. Searing's letter transmits a resolution presented to Whitman praising his work. Wayne State University, Archive of Labor and Urban History.

\section{9}

Late May. From Elizabeth Porter Gould. Gould's full letter is lost, but she copied the poem she enclosed to be read at Whitman's seventieth birthday party into several gift copies of her book Gems from Walt Whitman. The inscription reads:

Lines sent to the dinner (5 P. M.) given in honor of Walt Whitman's seventieth birthday at Camden N. J. May 311889.

"Splendor of ended day floating and filling me" Comes to my mind as I think of the hour When our poet and friend will be lovingly drinking The mystical cup of the seventy years' power.

Were I the man-of-war bird he has pictured, Nothing could keep me from flying that way, But though absent in body, there's nothing can hinder My tasting the joys of that fictive birthday:

As on the swift wings of the ending day: splendor My soul will glide in to drink deep the cup's wealth Who knows but the poet; keen sense of pure friendship Will feel the joy, what I drink to his health.

Splendor of ended day

Be but the door

Opening the endless way

Life evermore.

E. P. G. 
Much to Gould's disappointment, her lines were not included in Camden's Compliment to Walt Whitman. See her letter to Whitman, December 30, 1889, in Feinberg.

\section{1}

February 22. From Mrs. J. S. Harris of Cumberland Center, ME, asking for an autograph and suggesting that they may be related. Trent.

May 26. From Dr. Robert Fletcher at the Army Medical Museum in Washington, D.C. "I infer from a recent article in the New England Magazine that the latest Edition of your books, and the one, perhaps, which you regard as the most accurate, is to be obtained directly from you. If this be the case, will you kindly inform me of the amount which I may send as the price of a copy?" In $D B N$ Whitman noted: "June 2 sent big book to Dr Fletcher Army Medical Museum / Wash'n D C. by express." David J. Holmes Autographs.

\section{UNDATED}

Undated letter. From Samuel S. Powell, asking for WW's support as a candidate for mayor. Pennsylvania. 